\title{
電力系統用保護リレー装置の ディジタル化と技術の変遷
}

佐藤 茂

(株)東芝

ディジタルリレー，ディジタル保護リレ一適用の効果，技術動向

\section{1. はじめに}

保護リレー誕生から 100 年を記念して 2007 年に本誌の 技術探索記事に「保護リレー 100 年」が掲載された。本稿 ではこの中で述べられた 100 年の歴史のうち, ディジタル リレーが誕生してから現在までの 30 年間を振り返り,「デ イジタルリレーがもたらしたものは何か」を考えながら， 発展の歴史とその延長にある今後を展望してみたい。

\section{2. ディジタルリレーの誕生}

\section{1 ディジタルリレー開発の小史}

ディジタルリレーに関する最初の論文は 1968 年のアメ リカの G.D.Rockfeller 氏の論文とされている。当時はマイ クロコンピュータ (マイコン) の出現以前のため, 実現手 段としては大型のプロセスコンピュータしかなく, 装置規 模が大きすぎて実用的なレベルには程遠い状況であった。 しかし, マイコンの出現以来ディジタルリレーの現実性は 急に増大し, 1970 年代に入ってからは各国でマイコンを
使ったディジタルリレーの研究が盛んに行われるようにな った。我が国でも電力会社とメーカの共同研究を中心に開 発が行われ, 1980 年, 世界初のディジタルリレーが日本 で実用化された（図 1）。

\section{2 ディジタルリレー開発の目的}

（1）保護リレ一の役割と責務

ディジタルリレーの開発目的を眺める上で, 保護リレー とは何か, どんな役割と責務を持っているか, を簡単に振 り返っておく。

保護リレーとは, 電力系統に発生した何らかの擾乱を検 出し, その影響を電力系統から切り離す指令を遮断器など に与えるものである。擾乱のうち, 最も代表的なものが落 雷事故であり，送電線や鉄塔への落雷があると多大なエネ ルギーによって碍子の絶縁が破れ地絡事故や短絡事故が発 生する。保護リレーはこれらを，確実に，かつ高速に，物 理的に切り離せる最小の領域を検出（選択）することが要 求される。この確実性 (信頼性), 高速性, 選択性こそが 保護リレーの基本責務であり, 保護リレー誕生から 100 年

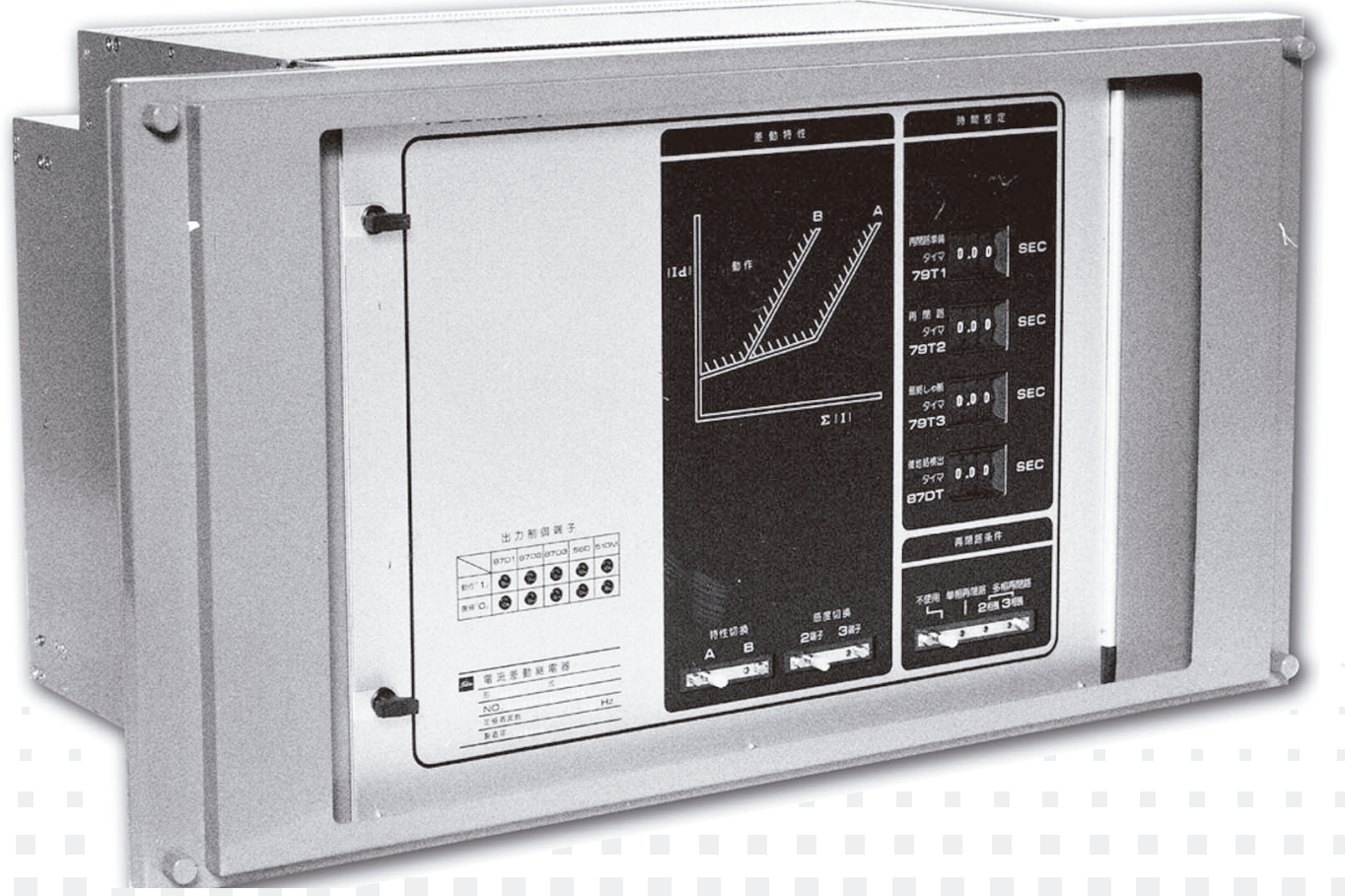

図 1 世界初のディジタルリレー 
の間，変更はない。これらを追求するためにさまざまな開 発が行われてきた。

（2）ディジタルリレ一開発の目的

当然, ディジタルリレーの開発もこの保護リレーの責務 向上が主目的であるが，それ以外にもディジタル化の特徵 を生かした, 小型化, 標準化, 保守性の向上などの保守運 用面の向上にも大きな期待が寄せられた。

1986 年に発刊されたディジタルリレーに関する我が国 初の電気協同研究報告 ${ }^{(1)} に は$, ディジタルリレー開発の目 的として,

(1)新しい保護機能の創出および高性能化

(2)保守の省力化, 高信頼度化

(3)小型化

(4)標準化指向

が挙げられている。

それらの実現の具体例としては，送電線の相手端の電流 を使った PCM 差動保護リレー（以後，PCM リレー），自 動監視の強化による無保守無点検化, 不要動作防止対策と してのフェイルセーフ概念（1つの不良で誤動作させない 日本独自の信頼度向上策。ハード的に独立したユニットと の AND で遮断指令を行う。), などが代表的な例として挙 げることができる。

\section{3 ディジタルリレーの特異性}

他のディジタル製品と比べてディジタルリレーを実現す るためには，いくつかの技術的困難を克服しなければなら ない。機能的に見た場合, 最も重要なものはリアルタイム 性である。電力系統の電流，電圧をデイジタル信号として 取り达み, これを使用して各種アルゴリズムで保護演算を 行い，保護区間内外を判断して遮断指令を送出するまでの 時間を, 事故発生から数 10 ミリ秒で行うことを保証しな ければならない。このため, 基本的には電気角で $30^{\circ}$ (1.667 ms/50 Hz, $1.389 \mathrm{~ms} / 60 \mathrm{~Hz})$ の周期でアナログ信 号をサンプリングし，このサンプリング間隔時間内にすべ ての保護演算を行う。通常の OS（オペレーティングシス テム）などでは，このような高速なタスクの実行をサポー 卜できないため, 開発当初は OS を使わないアセンブラ言 語による直接プログラミングが主流であったが, 組込み型 のリアルタイム OS が開発されてから（ $\mu$-ITRONなど）C 言語などの高級言語が使用できるようになり，より複雑な 機能やユーザインタフェースが可能になってきた。また,

扱うべき入力のレンジ幅が大きい（電流では数 $100 \mathrm{~A}$ か ら数万 A), ノイズ環境が厳しい, 差動保護での高精度な 時刻同期，なども他のディジタル製品と異なる大きな特徵 である。更に運用面で見ると，予定された停止以外では一 瞬たりとも停止は許されず，基本的には製品寿命（数 10
年程度）の間は無停止が要求される。このため, ファンや ハードディスクなどの回転体は使用できない，といった制 約の中で長期間稼動し続けるハードウェアが必要である。

\section{3. ディジタルリレーの普及}

\section{1 対象装置の広がりと適用技術の変遷}

PCM リレーで始まったディジタル保護リレーは，その 後 1980 年の $66 \mathrm{kV}$ 系統での回線選択保護装置を初めとし て適用が徐々に拡大していくが, 開発当初のディジタルリ レー（初期形）はバイポーラ形素子を採用していたことに より発熱が課題で，ファンなどの回転体は使用できないた め特殊なヒートパイプを取り付けて発熱問題を解決してい た。しかし演算素子の進歩は目覚ましく，その後数年で発 熱が少ないMOS 型の高速演算可能な素子が出現し, ディ ジタルリレーはMOS 型を使ったシリーズへと移っていく (この世代のものを第 1 世代と呼ぶ)。初期形では, その適 用はまだ限定的であったが，第 1 世代シリーズが開発され た 1985 年以降，ディジタルリレーの全国での適用数は飛 躍的に伸びていき，保護リレーの主役になった。表 1 に ディジタルリレーの普及率の推移を示す。

またその間に, 32 ビット CPU や 16 ビット A/D 変換器 の採用により，高速なサンプリング（電気角で $3.75^{\circ} ）$ や 入力電気量に含まれる高調波成分を除去するための高度な ディジタルフィルタ処理が可能となり, 経年的に特性変化 をもたらす可能性のあるアナログフィルタを大幅に簡素化 できたことで，ょり一層の無保守無点検化が図られてき た。

\section{2 機能の拡張}

機能の拡張を考えるには, 方式的な面での拡張と, アル ゴリズム面での拡張を分けて考えた方が分かりやすい。方 式的な面とはいわゆる保護方式といわれているもので, 過 電流・距離 - 回線選択 ·方向比較 ·位相比較 - 電流差動方 式，などが代表的なものである。デイジタルリレー出現ま でに，これらの方式はすべて実現されており，デイジタル 化ゆえの方式はないが, 電流差動方式においてサンプリン グしたディジタル電流信号を相手端子と送受信する，いわ ゆる PCM 電流差動方式はディジタル化の産物である。こ の方式は通信技術に負うところが大きく，世界に先駆けて 日本で PCM リレーが実用化されたのも, 高品質で信頼度

表 1 ディジタルリレーの普及率の推移

\begin{tabular}{|l|c|c|}
\hline & 1997 年 & 2007 年 \\
\hline 直接接地系統 & $60.0 \%$ & $82.4 \%$ \\
\hline 高抵抗接地系統 & $40.6 \%$ & $59.2 \%$ \\
\hline
\end{tabular}


の高い通信網*を電力会社が独自に構築しているという, 世界的にも類を見ない恵まれた環境があったからと言って も過言ではないだろう。

一方，アルゴリズム面での機能拡張には目をみはるもの がある。ソフトウェアによりさまざまな演算を自由に行 い, 機能を実現できるディジタルリレーの特徵を生かし,

これまで実現できなかった複雑なリレー特性や系統の状態 に自動的に適合するアダプティブリレーなどが実現されて いる。母線保護における CT 飽和対策 (事故時にCT が飽 和しても誤動作させない対策）は, 電流差動保護の弱点を カバーし適用対象を拡大させた例であり，事故時の電圧の 大きさにより PCM リレーの動作感度をアダプティブに変 化させる分岐負荷対策用 PCM (図 2), 保護対象の熱的履 歴や許容熱量などを考慮した OLR（過負荷リレー）など は,ディジタルリレーがゆえの特長を生かした代表的な例 といえる。飛躍的に性能向上を果たした現状の CPU 性能 からみると, 保護リレーはまだその能力を使い切ってはお らず, これからも電力系統のニーズ, 運用者のニーズに忘 えて新しいアルゴリズムが開発されていくものと期待され る。

\section{3 保護リレー以外への波及}

保護リレーのディジタル化が普及するとともに，保護リ レーと同様の信頼性や高速性を必要とするシステム, また は，保護リレーと同じようなアルゴリズムが適用できる装 置などへの適用が拡大している。電力系統の安定化システ ムはその代表的なものの1つで, 最もディジタル化の恩恵 を受けたシステムともいえる。安定化システム（事故波及 防止システムともいう）は, 事故を適切に除去できても事 故と事故除去の影響により電力系統が安定に運用できない 場合に，適切な処置を実施して系統の安定運用を継続でき るようにするもので, 対象とする現象は, 「過渡安定度」,

「周波数」, 「電圧安定度」, 「過負荷」などがある。安定化 システムは 1960 年代からその必要性が論じられ, いくつ
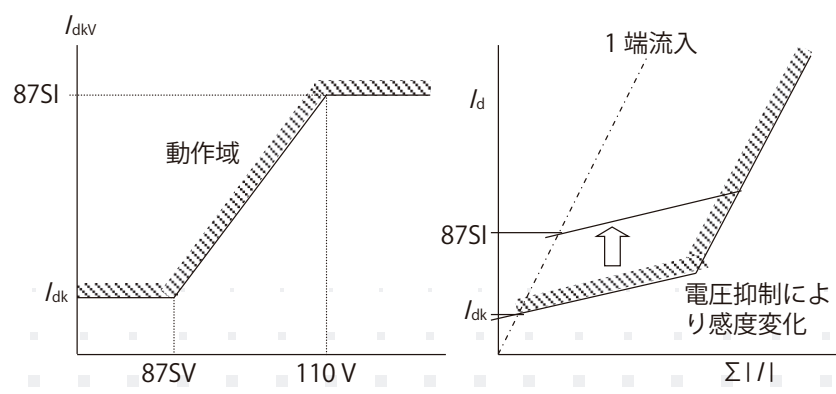

図 2 分技負荷対策用 PCM リレーの特性

* 伝送遅延時間 : $4 \mathrm{~ms}$, 遅延時間変動： $160 \mu \mathrm{s}$ 以下 $(60 \mathrm{~Hz}$ 系の数值) 伝送品質 (符号誤り率) $: 1 \times 10^{-7}$ 以下
かの実用装置が導入されていたが，アナログ回路で実現で きる機能には限界があり，適用は限定的なものであった。 しかし，ディジタルリレー技術の出現により，実現できる 機能の限界が取り払われ，更に，1970年代以降の急速な 電力系統の拡大により系統運用の厳しさも急速に増してき たことから，系統安定化システム導入へのニーズも高まっ てきたため, 飛躍的に発展してきたものである。比較的口 一カルなものから, 大型計算機と機能分担を図りながら広 域な電力系統の安定化制御を実現するものまで, 高速な演 算能力と通信処理能力を生かしたさまざまなシステムが実 用化されている（図3)。

保護の分野以外でも, 制御や故障点標定の分野でもディ ジタルリレーのハード，ソフトを活用したディジタル化が 普及しており，現在ではすべての保護，制御装置がディジ タル化された変電所も多数出現している。

\section{4. ディジタルリレー適用の効果}

以上，ディジタルリレーの誕生から普及していくまでを 概観してきたが，本章ではディジタルリレー適用の効果 を，すなわち，保護リレーのディジタル化が電力系統やそ の運用にどのような影響をもたらしたのか, という観点か ら眺めてみる(4)。

\section{1 電力系統の拡大, 大電力送電への貢献}

日本では 1970 年以降, 電力の総需要が飛躍的に増大 し，これに対応して電力系統・設備も拡大してきたが，設 備形成の制約から, 電源の遠隔・偏在化が進み, 必然的に 電力系統の大電力送電, 多重ループ構成運用が顕著になっ てきた。このような状況の中でディジタルリレーおよび系 統安定化システムは従来多発していた広範囲波及事故を防 止し, 系統信頼度の大幅向上, 系統セキュリティの確保な どに大きく貢献してきている。従来不可避であった送電線 2 回線同時事故による広範囲系統波及を, PCM リレーの 持つ優れた事故選択性と多相再閉路機能により防止してき ている。更に少し古い例では, 首都圈に供給している送電 線 2 回線が飛行機の接触により切断され, 首都圈と周辺都 市の広い範囲で供給が断たれた事故では安定化システムが 適切に動作し, 都心重要地域への供給継続に成功した事例 もある。

\section{2 設備形成の効率化, 設備形成制約への対応強化}

\section{（1）多端子構成による設備形成の効率化}

新しい送電線が必要になった場合, 既存の送電線を T 分 岐して系統を拡充する方が，すべてを新たに建設する場合 に比べて効率的な場合がある。1970 年以前は,このような 多端子送電線はその保護が困難であったため（方向比較や 位相比較方式でもある条件下では 3 端子までは可能), そ 


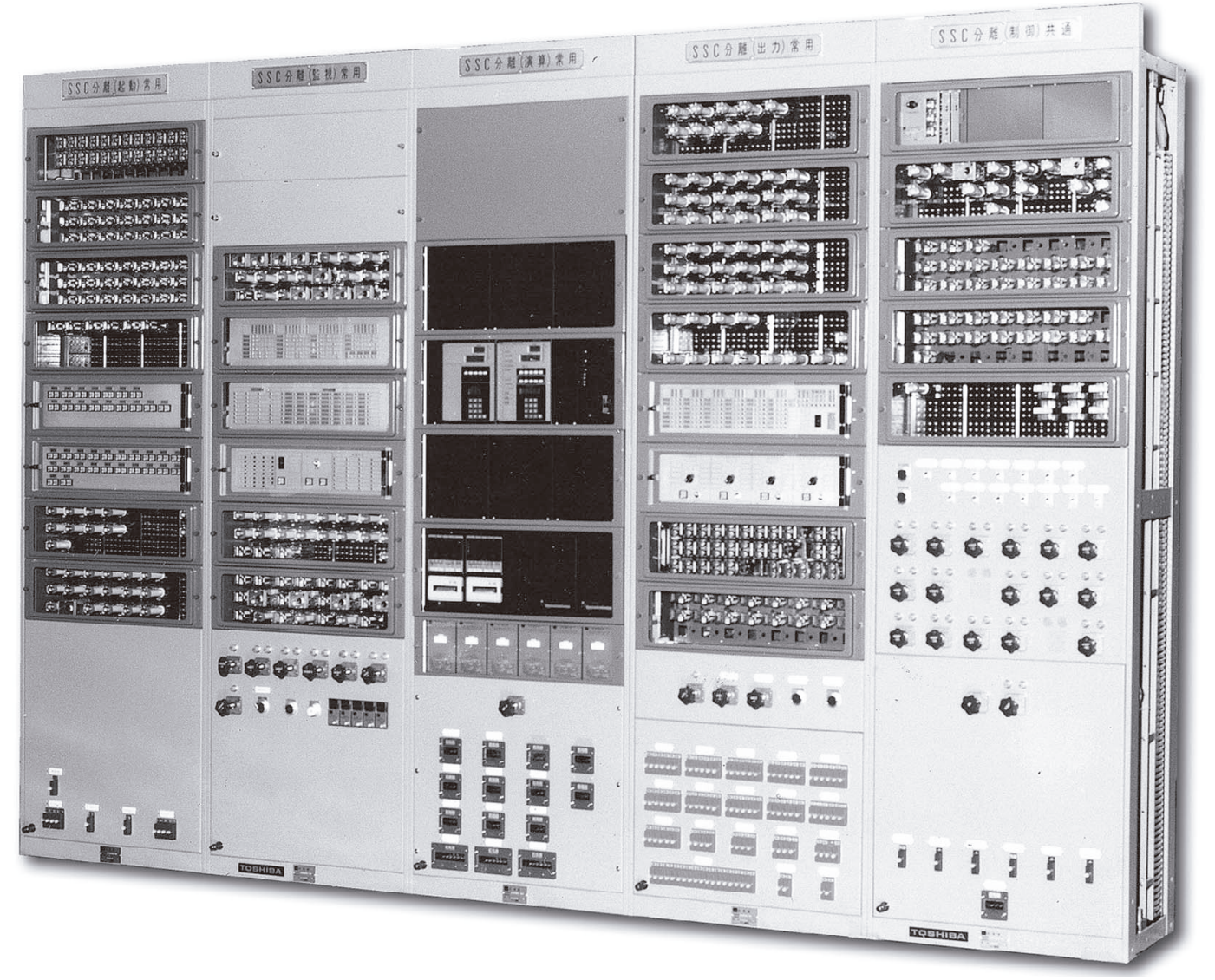

図 3 系統安定化システム

の導入は限定的であったが, PCM 電流差動リレーを適用 することでほとんど保護上の制約は取り払われ，超高圧系 統の 3 端子構成やそれ以上の多端子構成が可能となった。 $275 \mathrm{kV} 6$ 端子送電線の例では，200 億円に達する設備投資 の削減が図れるなど，送電線設備形成の効率化に大きく貢 献してきた。

（2）流通設備, 系統運用の効率化促進

送電設備自身にはまだ余裕があっても, 系統の常時の安 定化性や事故発生時の安定性の面から, 送電できる電力の 大きさに制約が生じ, 設備の能力を十分に発揮できない場 合がある。ディジタルリレーの出現により，保護リレーに 要求される責務が向上したことでこれらの制約が緩和さ れ, 効率的な設備運用や系統運用が実現されている。保護 リレーの高速化は, 例えば事故発生から 3 サイクルの事故 遮断を保証できれば，従来 4 サイクル遮断を前提にしてい た系統運用を緩和し，より大きな限界潮流を前提にした系 統運用を可能とする。更に系統安定化システムの高度化に より, 電源計画や系統運用計画の自由度が増大し, 従来な ら大幅な設備の増強で対処せざるを得ない場合でも, 現状 設備での対応を可能とした。こういった点で, 保護リレー のディジタル化は設備の効率化と系統・電源運用の効率化
に貢献している。

\section{3 装置の保守運用性の向上}

保護リレーのディジタル化は保護継電装置の保守運用の 簡素・効率化にも大きく貢献している。ディジタルリレー の持つ強力な自動監視機能（自動点検，常時監視）によ り，機能に影響がある不良のほとんどは事前に発見可能で あり，これまでの定期点検期間の大幅な延長または省略を 可能にした。また, ヒューマンインタフェースの向上と通 信を利用した遠隔運用システムの導入により, 従来現場で 実施していた整定業務や装置動作時の詳細情報の閲覧・解 析, 不具合発生時の不良内容の確認などが保守員のいる電 カセンタなどの遠方から可能になり, 保守運用業務の効率 化に寄与するとともに，復旧の迅速化にも貢献している。 その他, 装置の小型化による設置スペースの低減, 入力回 路の低負担化による計器用変成器 $(\mathrm{CT} / \mathrm{VT})$ などの主機 の小型化などにも貢献している。

\section{5. 近年の技術動向}

近年，保護制御技術と通信との関係はますます密になっ てきており, 海外では変電所構内でもさまざまな装置間を LAN で連係したり, 変電機器との間も高速な伝送で結合 


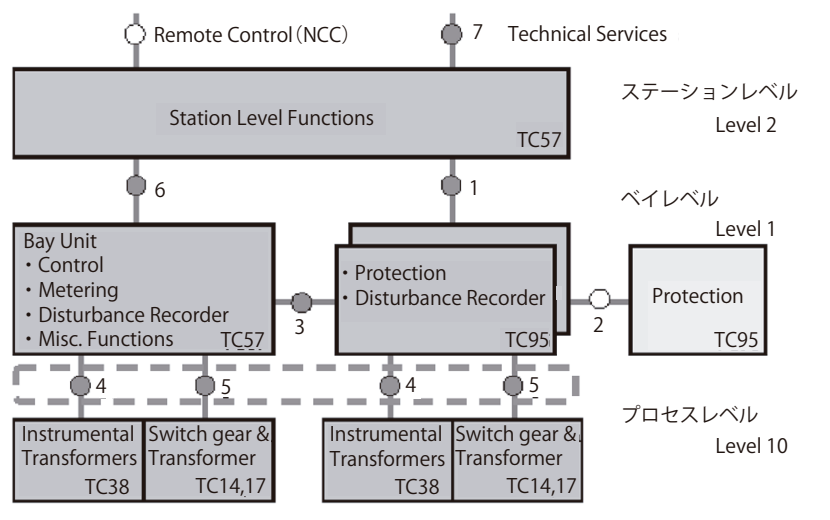

図 4 IEC61850 規格化の概要（IEC TC57 規格引用）

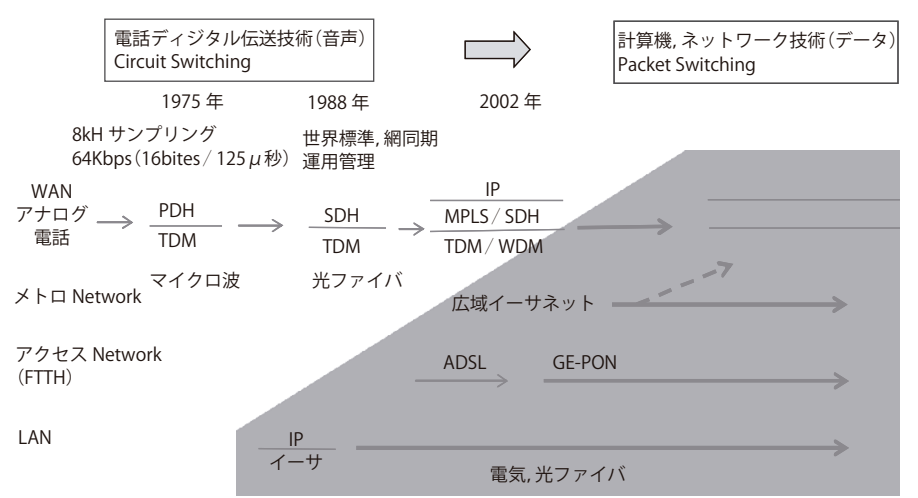

図 5 広域通信技術の動向

し，機器と直接ディジタル信号をやり取りするオールディ ジタル変電所まで出現している。これら保護制御と通信の 融合度合いが大きくなると，さまざまなべンダの装置が同 一の LAN に接続されて運用されることを想定する必要が あり, 標準・規格化が重要となる。IEC61850は変電所の 保護・制御装置全体を規格に基づいてディジタル化し, 変 電所の装置・機器を相互運用する目的で 2005 年に Edition1 として規格化が完了し，引き続きEdition2 の規 格化が継続している（図 4）。

IEC61850については，国内で適用するためには論理モ デルの拡張が必要, フェイルセーフリレーをネットワーク 上でどのように構成するか，など，いくつかの課題が指摘 されている。一方，インターネットの急速な発展・拡大と 電力会社における光ファイバ網の拡充により, 電力の通信 網も大きな変貌を遂げてきている。既に一部の電力会社で は全電気所にIP 網が構築されており, 近い将来には大半 の電力で構築されるものと思われる。IP 網を PCM リレー に適用するには，技術的にはサンプリング同期が最大の課

\section{文献：}

（6）電気学会：技術報告第 1203 号「変電所監視制御システム技術」(2010)

（1）電気協同研究会：「ディジタルリレー」, Vol. 41, No. 4 (1986)

（2）電気協同研究会：「第二世代ディジタルリレー」Vol. 50, No. 1 （1994）

（3）電気協同研究会：「電力用通信網への IP ネットワーク適用性評価・シ ステム設計技術」, Vol. 58, No. 4 (2002)

（4）電気協同研究会：「保護リレーの新しい機能・性能」, Vol. 65, No. 2 (2009)

(5) G. D. Rockefeller : 「Fault Protection with a Digital Computer」, IEEE Trans.PAS, Vol. 88, No. 4, pp. 438-464（1964）

題であるが，既にいくつかの方式が研究され実用化も近 い。現在, 電気学会調査専門委員会で保護リレーへの汎用 通信網の利用について調査中であり，「技術報告」が 2012 年に発行される予定である（図 5)。

また, スマートグリッド構想や送電線広域監視制御シス テム（WASA）などでも，ディジタルリレー技術の適用 は必須であり，国家プロジェクトとしても国際標準化活動 が精力的に行われている。世界初のディジタルリレーを実 用化した我が国の保護リレー技術で，国際的な貢献ができ ることは関係技術者として限りない喜びである。

\section{6. おわりに}

30 年前, 先輩たちが開発したディジタルリレーは, 保 護リレーの適用性を飛躍的に拡大し新しい可能性の扉を開 いた。ほとんどの保護リレーがディジタル化された今日， 我々は次の扉を開く鍵を準備しなければならない。

30 年前, 30 歳前後の若き開発技術者たちの夢が実を結 んだように，これからの若き技術者の熱意に期待したい。

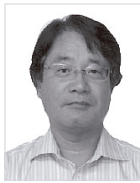

\section{佐藤 茂}

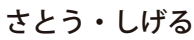

1973 年 4 月，(株) 東芝に入社。主として電力系統の保護・制御・ 安定化システム・系統解析シミュレータなどに関する企画，開発に 従事。現在，東芝システムテクノロジー(株)に勤務。 